\title{
The Role of Vessel Density as Measured by Optical Coherence Tomography Angiography in the Evaluation of Pseudoexfoliative Glaucoma: A Review of the Literature
}

\author{
Irini Chatziralli (D) - Ilias Milionis · Aikaterini Christodoulou • \\ Panagiotis Theodossiadis · George Kitsos
}

Received: August 18, 2021 / Accepted: February 7, 2022 / Published online: February 24, 2022

(C) The Author(s) 2022

\section{ABSTRACT}

Introduction: To review the existing literature about the optical coherence tomography angiography (OCTA) findings regarding peripapillary and macular vessel density (VD) in patients with pseudoexfoliative glaucoma (PXG).

Methods: A comprehensive search of the PubMed database was conducted to include articles up to November 1, 2021, using an appropriate search algorithm. The retrieved articles were assessed for eligibility and filtered manually to exclude duplicates, while articles and book chapters cited in the reference lists of the eligible articles obtained by this method were reviewed so as not to miss any relevant studies.

Results: There is consistency among the studies published so far that a significant decrease in peripapillary VD exists in eyes with PXG compared to controls, and macular VD has also been reported to be significantly lower in PXG eyes than controls. However, the existing literature

I. Chatziralli $(\bowtie) \cdot$ P. Theodossiadis

Second Department of Ophthalmology, National and Kapodistrian University of Athens, 1, Rimini Street, 12462 Haidari, Greece e-mail: eirchat@yahoo.gr

I. Milionis · A. Christodoulou - G. Kitsos Department of Ophthalmology, University of Ioannina, Ioannina, Greece remains controversial regarding OCTA findings in eyes with PXG compared to those with primary open-angle glaucoma (POAG). Several studies have found that peripapillary VD and macular VD were significantly lower in PXG than POAG, while other studies reported no significant difference.

Conclusions: Eyes with PXG were found to present decreased peripapillary and macular VD compared to control eyes, suggesting that a vascular component, including optic nerve hypoperfusion, may be implicated in the pathogenesis of PXG.

Keywords: Foveal Avascular Zone; Glaucoma; OCT Angiography; Peripapillary; Pseudoexfoliation; Vessel Density

\section{Key Summary Points}

A significant decrease in peripapillary and macular vessel density has been reported in eyes with pseudoexfoliative glaucoma in comparison with control subjects.

No general consensus exists regarding the optical coherence tomography angiography findings in patients with pseudoexfoliative glaucoma compared to patients with primary open-angle glaucoma. 


\section{INTRODUCTION}

Pseudoexfoliation syndrome (PXS) was initially described by Lindberg in 1917 and is considered a complex age-related systemic disorder of the extracellular matrix, primarily affecting the eye [1], although visceral organs, such as the lungs, liver, kidneys, gall bladder, heart and cerebral meninges, can also be involved [2-4]. In the eye, PXS is characterized by the production and progressive deposition of fibrillar material, which can be observed during slit-lamp examination as "dandruff-like" flakes in the anterior chamber, at the pupillary margin, on the lens zonules, on the trabecular meshwork and on the anterior lens capsule, forming a characteristic double concentric ring pattern [5]. It is worth noting that PXS has been associated with increased risk of glaucoma and cataract, with predisposition to intraocular complications during surgery [6].

Pseudoexfoliative glaucoma (PXG) is the most common identifiable cause of secondary open-angle glaucoma (OAG) worldwide, accounting for $25-70 \%$ of OAG and involving a high risk of blindness $[7,8]$. The cumulative risk of developing glaucoma in patients with PXS has been estimated at approximately $5.3 \%$ and $15.4 \%$ at 5 and 10 years, respectively [9]. In PXG, accumulation of fibrillar extracellular material occurs, obstructing the aqueous humor outflow pathways, which in turn causes increased intraocular pressure (IOP) and subsequent glaucomatous optic nerve damage $[8,10]$. PXG is often characterized by higher IOP and greater IOP fluctuation, resulting in faster progression compared to primary OAG (POAG) $[6,11,12]$. However, PXG with controlled IOP has also been reported to progress more rapidly than POAG, suggesting that an IOP-independent pathogenic mechanism exists in PXG [13]. Specifically, the thickness and stiffness of the lamina cribrosa was thinner and lower in PXG patients compared with those in POAG patients $[14,15]$. Moreover, previous studies have suggested that a vascular mechanism, including decreased ocular blood flow and consequent reduced optic nerve perfusion due to changes in the blood vessel walls and endothelial dysfunction, may be implicated in the pathogenesis of PXG $[16,17]$.

Various methods have been used to measure optic nerve head perfusion in both POAG and PXS [18]. Fluorescein angiography has been applied to measure vascular blood flow; however, it is both invasive and inaccurate for the measurement of optic nerve head perfusion, while laser speckle flowmetry and Doppler imaging are operator-dependent and do not provide adequate visualization $[19,20]$. Optical coherence tomography angiography (OCTA) is a relatively new noninvasive imaging technology, allowing visualization of the retinal microcirculation, also providing quantitative analysis of the peripapillary and macular microvasculature $[21,22]$. Since it has been hypothesized that impaired vascular supply may also be involved in the pathogenesis of PXG, several studies have used OCTA to investigate peripapillary and macular microcirculation in eyes with PXG and PXS [20, 23-37]. Based on the above, the purpose of this review is to assess the peripapillary and macular vessel density (VD) as measured using OCTA in eyes with PXG, as well as to compare these OCTA parameters in eyes with PXG with those of either eyes with POAG or normal eyes, based on findings reported in the existing literature.

\section{METHODS}

A comprehensive search of the PubMed database was conducted to include articles up to November 1, 2021, using the following search algorithm: [("pseudoexfoliative" OR "pseudoexfoliation" OR "exfoliation" OR "exfoliative") AND ("glaucoma") AND ("optical coherence tomography angiography" OR "OCT angiography" OR "OCTA" OR "vessel density" OR "blood flow" OR "vascularity")]. The retrieved articles were assessed for eligibility and filtered manually to exclude duplicates, while articles and book chapters cited in the reference lists of the eligible articles obtained by this method were reviewed, so as not to miss any relevant study. No language restrictions were set. This article is based on previously conducted studies and does not contain any new 
Table 1 Characteristics and main findings of the studies included in the review

\begin{tabular}{|c|c|c|c|c|c|c|}
\hline Study & Region & Study Design & N Eyes & $\begin{array}{l}\text { Imaging } \\
\text { Model- } \\
\text { Protocol }\end{array}$ & Key Messages & Limitations \\
\hline Suwan [23] & $\begin{array}{l}\text { New } \\
\text { York }\end{array}$ & $\begin{array}{l}\text { Cross- } \\
\text { sectional }\end{array}$ & $\begin{array}{l}33 \text { PXS } \\
43 \text { PXG } \\
31 \\
\text { POAG } \\
45 \\
\text { controls }\end{array}$ & $\begin{array}{l}\text { AngioVue } \\
\text { Avanti } \\
\text { RTVue XR, } \\
\text { OptoVue- } \\
4.5 \times 4.5\end{array}$ & $\begin{array}{l}\text { Both POAG and } \\
\text { PXG demonstrated } \\
\text { decreased perfused } \\
\text { capillary density } \\
\text { compared to } \\
\text { controls } \\
\text { PXG demonstrated } \\
\text { significantly lower } \\
\text { perfused capillary } \\
\text { density values } \\
\text { compared to POAG, } \\
\text { after adjusting for } \\
\text { age and stage }\end{array}$ & $\begin{array}{l}\text { Small sample size } \\
\text { High proportion of } \\
\text { older-age patients in } \\
\text { the PXS and PXG } \\
\text { groups (age and } \\
\text { stage-adjustment) }\end{array}$ \\
\hline Park [24] & Korea & $\begin{array}{l}\text { Cross- } \\
\text { sectional, } \\
\text { retrospective }\end{array}$ & $\begin{array}{l}39 \text { PXG } \\
39 \\
\text { POAG }\end{array}$ & $\begin{array}{l}\text { DRI OCT } \\
\text { Triton; } \\
\text { Topcon, } \\
\text { Tokyo, } \\
\text { Japan }\end{array}$ & $\begin{array}{l}\text { Average peripapillary } \\
\text { VD was significantly } \\
\text { lower in PXG than } \\
\text { in POAG with } \\
\text { similar severity }\end{array}$ & $\begin{array}{l}\text { Small sample size } \\
\text { Retrospective design } \\
\text { Lack of control group } \\
\text { Probably included } \\
\text { normal-tension } \\
\text { glaucoma eyes }\end{array}$ \\
\hline Rebolleda [25] & Spain & $\begin{array}{l}\text { Cross- } \\
\text { sectional }\end{array}$ & $\begin{array}{l}20 \text { PXG } \\
20 \\
\text { POAG } \\
20 \\
\text { controls }\end{array}$ & $\begin{array}{l}\text { AngioVue } \\
\text { Avanti } \\
\text { RTVue XR, } \\
\text { OptoVue- } \\
4.5 \times 4.5 \\
\text { AngioPlex, } \\
\text { Zeiss }\end{array}$ & $\begin{array}{l}\text { Peripapillary capillary } \\
\text { VD was significantly } \\
\text { lower in PXG than } \\
\text { in POAG } \\
\text { Both machines } \\
\text { showed that } \\
\text { peripapillary } \\
\text { capillary VD was } \\
\text { lower in PXG and } \\
\text { POAG than controls }\end{array}$ & Small sample size \\
\hline
\end{tabular}


Table 1 continued

\begin{tabular}{|c|c|c|c|c|c|c|}
\hline Study & Region & Study Design & N Eyes & $\begin{array}{l}\text { Imaging } \\
\text { Model- } \\
\text { Protocol }\end{array}$ & Key Messages & Limitations \\
\hline Philip [26] & $\begin{array}{l}\text { New } \\
\text { York }\end{array}$ & $\begin{array}{l}\text { Cross- } \\
\text { sectional }\end{array}$ & $\begin{array}{l}26 \text { PXG } \\
28 \\
\text { POAG }\end{array}$ & $\begin{array}{l}\text { AngioVue } \\
\text { Avanti } \\
\text { RTVue XR, } \\
\text { OptoVue- } \\
3 \times 3 \\
\text { macula }\end{array}$ & $\begin{array}{l}\text { PXG presented } \\
\text { statistically } \\
\text { significantly lower } \\
\text { macular VD in the } \\
\text { SCP in all areas } \\
\text { compared to } \\
\text { POAG, even after } \\
\text { correction for age, } \\
\text { stage, axial length, } \\
\text { race }\end{array}$ & $\begin{array}{l}\text { Small sample size } \\
\text { High proportion of } \\
\text { older age patients in } \\
\text { the PXG group }\end{array}$ \\
\hline Pradhan [27] & India & $\begin{array}{l}\text { Cross- } \\
\text { sectional, } \\
\text { prospective }\end{array}$ & $\begin{array}{l}39 \text { PXG } \\
39 \\
\text { POAG }\end{array}$ & $\begin{array}{l}\text { AngioVue } \\
\text { Avanti } \\
\text { RTVue XR, } \\
\text { OptoVue- } \\
4.5 \times 4.5 \\
\text { ONH and } \\
3 \times 3 \\
\text { macula }\end{array}$ & $\begin{array}{l}\text { There was no } \\
\text { significant } \\
\text { difference in } \\
\text { peripapillary and } \\
\text { parafoveal } \\
\text { superficial VD } \\
\text { between PXG and } \\
\text { POAG } \\
\text { The choroidal } \\
\text { microvasculature } \\
\text { drop-out was } \\
\text { significantly lower in } \\
\text { PXG than in POAG }\end{array}$ & $\begin{array}{l}\text { Projection artifacts in } \\
\text { OCTA } \\
\text { Older age of PXG } \\
\text { compared to POAG } \\
\text { Selection bias, } \\
\text { including patients } \\
\text { visiting eye clinic } \\
\text { Effect of blood } \\
\text { pressure, systemic } \\
\text { antihypertensive } \\
\text { medications and } \\
\text { ocular hypotensive } \\
\text { drops was not } \\
\text { assessed }\end{array}$ \\
\hline Çınar [28] & Turkey & $\begin{array}{l}\text { Cross- } \\
\text { sectional }\end{array}$ & $\begin{array}{l}35 \text { PXS } \\
35 \\
\text { controls }\end{array}$ & $\begin{array}{l}\text { AngioVue } \\
\text { Avanti } \\
\text { RTVue XR, } \\
\text { OptoVue- } \\
6 \times 6 \\
\text { macula }\end{array}$ & $\begin{array}{l}\text { Significant difference } \\
\text { in superficial VD } \\
\text { between PXS and } \\
\text { controls } \\
\text { FAZ area was } \\
\text { significantly enlarged } \\
\text { in PXS in both SCP } \\
\text { and DCP compared } \\
\text { to controls }\end{array}$ & Small sample size \\
\hline
\end{tabular}


Table 1 continued

\begin{tabular}{|c|c|c|c|c|c|c|}
\hline Study & Region & Study Design & N Eyes & $\begin{array}{l}\text { Imaging } \\
\text { Model- } \\
\text { Protocol }\end{array}$ & Key Messages & Limitations \\
\hline $\begin{array}{l}\text { Lommatzsch } \\
\text { [29] }\end{array}$ & Germany & $\begin{array}{l}\text { Cross- } \\
\text { sectional, } \\
\text { prospective }\end{array}$ & $\begin{array}{l}21 \mathrm{PXG} \\
40 \\
\text { POAG }\end{array}$ & $\begin{array}{l}\text { AngioVue } \\
\text { Avanti } \\
\text { RTVue XR, } \\
\text { OptoVue- } \\
4.5 \times 4.5 \\
\text { ONH and } \\
6 \times 6 \\
\text { macula }\end{array}$ & $\begin{array}{l}\text { No significant } \\
\text { differences in the } \\
\text { papillary, } \\
\text { peripapillary and } \\
\text { macular VD } \\
\text { between PXG and } \\
\text { POAG }\end{array}$ & $\begin{array}{l}\text { Small sample size } \\
\text { Patients receiving } \\
\text { local anti- } \\
\text { glaucomatous agents } \\
\text { Exclusion of patients } \\
\text { with arterial } \\
\text { hypertension or } \\
\text { hypotension }\end{array}$ \\
\hline Jo [30] & Korea & $\begin{array}{l}\text { Cross- } \\
\text { sectional, } \\
\text { retrospective }\end{array}$ & $\begin{array}{l}49 \text { PXG } \\
49 \\
\text { POAG }\end{array}$ & $\begin{array}{l}\text { AngioVue } \\
\text { Avanti } \\
\text { RTVue XR, } \\
\text { OptoVue- } \\
4.5 \times 4.5 \\
\text { ONH and } \\
6 \times 6 \\
\text { macula }\end{array}$ & $\begin{array}{l}\text { No significant } \\
\text { difference in } \\
\text { peripapillary VD } \\
\text { between PXG and } \\
\text { POAG } \\
\text { Parafoveal VD in both } \\
\text { superficial and deep } \\
\text { plexus was } \\
\text { significantly lower in } \\
\text { PXG than POAG } \\
\text { Perifoveal VD only in } \\
\text { deep plexus was } \\
\text { significantly lower in } \\
\text { PXG than POAG }\end{array}$ & $\begin{array}{l}\text { Retrospective design } \\
\text { Selection bias, } \\
\text { including only } \\
\text { patients visiting eye } \\
\text { clinic }\end{array}$ \\
\hline Simsek [31] & Turkey & $\begin{array}{l}\text { Cross- } \\
\text { sectional, } \\
\text { prospective }\end{array}$ & $\begin{array}{l}40 \text { PXG } \\
40 \\
\text { controls }\end{array}$ & $\begin{array}{l}\text { AngioVue } \\
\text { Avanti } \\
\text { RTVue XR, } \\
\text { OptoVue- } \\
4.5 \times 4.5 \\
\text { ONH }\end{array}$ & $\begin{array}{l}\text { Significant decrease in } \\
\text { optic nerve head } \\
\text { VD in all regions in } \\
\text { PXG compared to } \\
\text { controls }\end{array}$ & Small sample size \\
\hline $\begin{array}{l}\text { Tangtammaruk } \\
\text { [20] }\end{array}$ & Thailand & $\begin{array}{l}\text { Cross- } \\
\text { sectional }\end{array}$ & $\begin{array}{l}31 \text { PXS } \\
32 \\
\text { controls }\end{array}$ & $\begin{array}{l}\text { AngioVue } \\
\text { Avanti } \\
\text { RTVue XR, } \\
\text { OptoVue- } \\
4.5 \times 4.5 \\
\text { ONH }\end{array}$ & $\begin{array}{l}\text { Significantly lower } \\
\text { peripapillary } \\
\text { capillary VD in PXS } \\
\text { than in control }\end{array}$ & $\begin{array}{l}\text { Small sample size } \\
\text { Any stage of PXS }\end{array}$ \\
\hline
\end{tabular}


Table 1 continued

\begin{tabular}{|c|c|c|c|c|c|c|}
\hline Study & Region & Study Design & N Eyes & $\begin{array}{l}\text { Imaging } \\
\text { Model- } \\
\text { Protocol }\end{array}$ & Key Messages & Limitations \\
\hline Köse [32] & Turkey & $\begin{array}{l}\text { Cross- } \\
\text { sectional, } \\
\text { retrospective }\end{array}$ & $\begin{array}{l}46 \text { PXG } \\
36 \\
\text { POAG } \\
23 \\
\text { controls }\end{array}$ & $\begin{array}{l}\text { AngioVue } \\
\text { Avanti } \\
\text { RTVue XR, } \\
\text { OptoVue- } \\
4.5 \times 4.5 \\
\text { ONH and } \\
6 \times 6 \\
\text { macula }\end{array}$ & $\begin{array}{l}\text { VD was significantly } \\
\text { lower in PXG and } \\
\text { POAG eyes than in } \\
\text { controls in all } \\
\text { peripapillary sectors } \\
\text { The average macular } \\
\text { SCP VD was } \\
\text { significantly lower in } \\
\text { PXG than in POAG }\end{array}$ & $\begin{array}{l}\text { Small sample size } \\
\text { Older patients with } \\
\text { PXG and POAG } \\
\text { (adjustment for age) } \\
\text { Patients on } \\
\text { antiglaucoma drops }\end{array}$ \\
\hline Subasi [33] & Turkey & $\begin{array}{l}\text { Cross- } \\
\text { sectional, } \\
\text { prospective }\end{array}$ & $\begin{array}{l}34 \text { PXG } \\
36 \\
\text { POAG }\end{array}$ & $\begin{array}{l}\text { AngioVue } \\
\text { Avanti } \\
\text { RTVue XR, } \\
\text { OptoVue- } \\
4.5 \times 4.5 \\
\text { ONH and } \\
6 \times 6 \\
\text { macula }\end{array}$ & $\begin{array}{l}\text { In PXG, all VD } \\
\text { parameters in the } \\
\text { macular region were } \\
\text { significantly lower } \\
\text { than in POAG } \\
\text { FAZ area was larger in } \\
\text { PXG than POAG, } \\
\text { but difference did } \\
\text { not reach } \\
\text { significance } \\
\text { Peripapillary VD was } \\
\text { significantly lower in } \\
\text { PXG than in POAG }\end{array}$ & $\begin{array}{l}\text { Small sample size } \\
\text { Lack of controls }\end{array}$ \\
\hline Safizadeh [34] & Iran & $\begin{array}{l}\text { Cross- } \\
\text { sectional, } \\
\text { prospective }\end{array}$ & $\begin{array}{l}41 \mathrm{PXS} \\
82 \mathrm{PXG} \\
57 \\
\text { controls }\end{array}$ & $\begin{array}{l}\text { AngioVue } \\
\text { Avanti } \\
\text { RTVue XR, } \\
\text { OptoVue- } \\
4.5 \times 4.5 \\
\text { ONH }\end{array}$ & $\begin{array}{l}\text { PXG presented lower } \\
\text { peripapillary VD } \\
\text { than controls and } \\
\text { PXS }\end{array}$ & $\begin{array}{l}\text { Small sample size } \\
\text { Confounding factors } \\
\text { that could influence } \\
\mathrm{VD} \text {, including } \\
\text { systemic } \\
\text { hypertension, } \\
\text { diabetes mellitus and } \\
\text { vasoactive } \\
\text { medications (both } \\
\text { topical and systemic) } \\
\text { were not excluded } \\
\text { Older patients in } \\
\text { PXG and POAG } \\
\text { (adjusting for age } \\
\text { and gender) }\end{array}$ \\
\hline
\end{tabular}


Table 1 continued

\begin{tabular}{|c|c|c|c|c|c|c|}
\hline Study & Region & Study Design & N Eyes & $\begin{array}{l}\text { Imaging } \\
\text { Model- } \\
\text { Protocol }\end{array}$ & Key Messages & Limitations \\
\hline Onur [35] & Turkey & $\begin{array}{l}\text { Cross- } \\
\text { sectional }\end{array}$ & $\begin{array}{l}18 \text { PXG } \\
18 \\
\text { POAG } \\
18 \\
\text { controls }\end{array}$ & $\begin{array}{l}\text { AngioVue } \\
\text { Avanti } \\
\text { RTVue XR, } \\
\text { OptoVue- } \\
3 \times 3\end{array}$ & $\begin{array}{l}\text { Peripapillary capillary } \\
\text { VD was significantly } \\
\text { lower in POAG and } \\
\text { PXG compared to } \\
\text { controls } \\
\text { Peripapillary capillary } \\
\text { VD did not differ } \\
\text { between POAG and } \\
\text { PXG }\end{array}$ & $\begin{array}{l}\text { Small sample size } \\
\text { Use of } 3 \times 3 \text { imaging } \\
\text { modality }\end{array}$ \\
\hline $\begin{array}{l}\text { Durmuş Ece } \\
\text { [36] }\end{array}$ & Turkey & $\begin{array}{l}\text { Cross- } \\
\text { sectional, } \\
\text { prospective }\end{array}$ & $\begin{array}{l}25 \text { PXG } \\
25 \\
\text { POAG } \\
25 \\
\text { controls }\end{array}$ & $\begin{array}{l}\text { AngioVue } \\
\text { Avanti } \\
\text { RTVue XR, } \\
\text { OptoVue- } \\
4.5 \times 4.5 \\
\text { ONH and } \\
6 \times 6 \\
\text { macula }\end{array}$ & $\begin{array}{l}\text { In glaucomatous eyes, } \\
\text { VD values were } \\
\text { significantly lower } \\
\text { than controls } \\
\text { No difference in VD } \\
\text { between POAG and } \\
\text { PXG }\end{array}$ & $\begin{array}{l}\text { Small sample size } \\
\text { Lack of blood pressure } \\
\text { parameters }\end{array}$ \\
\hline $\begin{array}{l}\text { Gür Güngör } \\
\text { [37] }\end{array}$ & Turkey & $\begin{array}{l}\text { Cross- } \\
\text { sectional }\end{array}$ & $\begin{array}{l}39 \text { PXS } \\
39 \\
\text { controls }\end{array}$ & $\begin{array}{l}\text { AngioVue } \\
\text { Avanti } \\
\text { RTVue XR, } \\
\text { OptoVue- } \\
4.5 \times 4.5 \\
\text { ONH and } \\
6 \times 6 \\
\text { macula }\end{array}$ & $\begin{array}{l}\text { No statistically } \\
\text { significant } \\
\text { difference in } \\
\text { peripapillary VD } \\
\text { between PXS and } \\
\text { controls } \\
\text { In the macular region, } \\
\text { superficial VD } \\
\text { parameters were } \\
\text { significantly lower in } \\
\text { PXS than controls }\end{array}$ & Small sample size \\
\hline
\end{tabular}


Table 1 continued

\begin{tabular}{|c|c|c|c|c|c|c|}
\hline Study & Region & Study Design & N Eyes & $\begin{array}{l}\text { Imaging } \\
\text { Model- } \\
\text { Protocol }\end{array}$ & Key Messages & Limitations \\
\hline Cornelius [38] & Germany & $\begin{array}{l}\text { Cross- } \\
\text { sectional, } \\
\text { prospective }\end{array}$ & $\begin{array}{l}26 \\
\text { POAG } \\
23 \text { PXG }\end{array}$ & $\begin{array}{l}\text { Cirrus HD- } \\
\text { OCT with } \\
\text { AngioPlex } \\
\text { Metrix }\end{array}$ & $\begin{array}{l}\text { The mean superficial } \\
\text { perifoveal plexus } \\
\text { perfusion density } \\
\text { was significantly } \\
\text { lower in PXG eyes } \\
\text { than in POAG eyes } \\
\text { The mean perfusion } \\
\text { density for } \\
\text { superficial } \\
\text { peripapillary plexus } \\
\text { did not differ } \\
\text { between POAG and } \\
\text { PXG eyes }\end{array}$ & Small sample size \\
\hline
\end{tabular}

$P X S$ pseudoexfoliation syndrome; $P X G$ pseudoexfoliation glaucoma; $P O A G$ primary open-angle glaucoma; $S C P$ superficial capillary plexus; $D C P$ deep capillary plexus; $V D$ vessel density; $F A Z$ foveal avascular zone; $O N H$ optic nerve head

studies with human participants or animals performed by any of the authors.

\section{RESULTS}

Table 1 summarizes the characteristics and the main findings of the studies included in this review. All studies were cross-sectional, either prospective or retrospective. In all studies except two, the AngioVue Avanti RTVue XR (Optovue, Fremont, CA) OCTA imaging model was used to measure the vessel density (VD) in various regions and foveal avascular zone (FAZ) area.

\section{Pseudoexfoliation Syndrome vs. Controls}

Three cross-sectional studies compared eyes with PXS with age-matched control eyes $[20,28,37]$. Regarding VD in the macular area, there was consistency in that a significant decrease in superficial VD was observed in eyes with PXS compared to controls [28, 37], accompanied by a significant enlargement in the FAZ area in both the superficial capillary plexus (SCP) and deep capillary plexus (DCP) in eyes with PXS compared to control eyes [28]. However, the findings related to peripapillary VD seemed to be contradictory, with Tangtammaruk et al. reporting a significant decrease in peripapillary perfused capillary density in eyes with PXS versus controls [20], in line with Suwan et al. [23], while Gür Güngör et al. found no significant difference in peripapillary VD between the two groups [37].

\section{Pseudoexfoliation Glaucoma vs. Controls}

Simsek et al., in a prospective, cross-sectional study, compared 40 eyes with PXG and 40 agematched control eyes and demonstrated that there was a significant decrease in peripapillary VD in all regions in eyes with PXG compared to controls [31], in agreement with other studies $[23,34-36]$, as well as with Köse et al., who found that both peripapillary and macular VD were lower in PXG eyes than in controls [32]. In addition, the abovementioned findings were in 
line with Rebolleda et al., who reached the same conclusion using two different OCTA machines [25].

\section{Pseudoexfoliation Glaucoma vs. Primary Open-Angle Glaucoma}

The existing literature remains controversial regarding the OCTA findings in eyes with PXG compared to POAG. Several studies have found that average peripapillary VD was significantly lower in eyes with PXG than in POAG eyes $[24,25,33]$, while peripapillary VD was found to be affected mainly in the inferonasal and nasal sectors $[24,26,32]$. Interestingly, a significant correlation between peripapillary VD and retinal nerve fiber layer (RNFL) thickness, as well as visual field defects, was also reported [24]. Moreover, macular VD was found to be lower in PXG compared to POAG [26, 32, 33], especially in the parafoveal area and perifoveal DCP [30]. Additionally, the FAZ area was reported to be increased in eyes with PXG compared to POAG, although it did not reach significance [33]. It is worth noting that these observations were independent of glaucoma severity, since they were observed with similar severity in PXG and POAG [24].

On the other hand, there are also studies which did not note any significant difference in peripapillary VD $[27,29,30,35,36,38]$ or in foveal and parafoveal VD [27, 29, 36] between eyes with PXG and POAG.

\section{DISCUSSION}

Our results clearly showed that eyes with PXG presented significantly decreased peripapillary and macular VD compared to controls. On the other hand, there is controversy regarding the OCTA findings in eyes with PXG compared to those with POAG, since most of the studies demonstrated that peripapillary and macular VD was lower in eyes with PXG than with POAG, but some authors reported finding no difference in OCTA parameters between PXG and POAG.

The discrepancy in the OCTA outcomes between eyes with PXG and POAG may be attributed to the different study design, methodologies and devices used in the studies published so far. Specifically, although most studies used the AngioVue Avanti RTVue XR OCTA system, there was no consistency among studies in the parameters examined, since several indices including global, annular or average VD were used; therefore, a quantitative analysis of the results, comparing eyes with PXG, POAG and controls, was not feasible. It should also be taken into account that in some studies the authors did not match the subjects' age or glaucoma severity between groups, and they used custom software to measure and compare VD, which may have affected their results $[23,24]$. The decreased VD in eyes with PXG compared to eyes with POAG corroborates the present understanding of PXG as a particularly aggressive type of glaucoma, which often progresses at a more rapid rate and responds more poorly to medical treatment compared to POAG. Similarly, prior studies reported increased vascular resistance in the ophthalmic artery in PXG [39].

The main mechanism of glaucomatous optic neuropathy in eyes with PXG has been considered to be mechanical damage due to elevated IOP, which causes the death of retinal ganglion cells [40]. However, it has been demonstrated that vascular abnormalities may be another important causative factor [10]. Specifically, pseudoexfoliative material has been shown to accumulate mainly in smaller vessel endothelial cells, smooth muscle cells and pericytes, which have a regulatory role in local microcirculation, further leading to extirpation of the vessel wall or obliteration of the lumen [41]. As a result, pseudoexfoliative deposits in vessels may cause circulation deficiency or occlusion, inducing ischemic changes. This hypothesis is supported by the fact that decreased peripapillary and macular VD has been observed in eyes with PXG.

It is worth mentioning that peripapillary VD has been found to be affected mainly in the inferonasal and nasal sectors [24, 32]. This can be explained by the fact that the nasal part of the lamina cribrosa in PXG eyes may be more vulnerable to glaucomatous damage. Yüksel et al. used color Doppler imaging to evaluate 
the orbital blood flow velocities and found that the peak systolic velocity and end-diastolic velocity of the posterior nasal ciliary artery were significantly decreased in PXG eyes compared to eyes with PXS [16]. The impaired retrobulbar blood flow in the nasal part of the lamina cribrosa might have induced weakness in the corresponding lamina cribrosa, rendering the nasal part more susceptible to glaucomatous damage.

An interesting point that should be noted is that in the macular area, the SCP was found to be mainly affected in eyes with PXG compared to POAG, although Jo et al. reported that VD was also significantly decreased in the parafoveal area and perifoveal DCP in eyes with PXG [30]. It is already known that the SCP is responsible for the metabolic supply of the ganglion cell layer, whereas the DCP is important for the nutrition of the inner nuclear layer, which comprises bipolar cells, horizontal cells and amacrine cells [42, 43]. Eltutar et al. demonstrated that the ganglion cell layer and superficial retinal layer were significantly thinner in eyes with PXS and that this thinning may be an early sign of PXG [42]. The reduced VD in the superficial retinal layers may explain the thinning of the ganglion cell layer, which has been described previously [42], or it could be secondary to a reduction in RNFL and ganglion cell layer. Longitudinal studies are required to understand the pathogenesis of reduced VD in patients with PXG.

Potential limitations of the review pertain to the inherent limitations of each separate study. Firstly, the sample size in some studies was small. Secondly, the cross-sectional and mainly retrospective design is a significant limitation of the included studies, while some of them lacked a control group. Additionally, there was high heterogeneity between the included studies, providing different OCTA parameters and values, and therefore precluding a quantitative analysis of the comparison between eyes with POAG, PXG and controls. Finally, measurement of the VD and FAZ area was performed using custom software, and artifacts should also be taken into account when analyzing the results of each study.

\section{CONCLUSIONS}

In conclusion, the current review clearly showed that eyes with PXG were found to present decreased peripapillary and macular VD compared to control eyes, suggesting that there is a vascular component, including optic nerve hypoperfusion, in the pathogenesis of PXG. Furthermore, the RNFL and ganglion cell loss should be considered to explain the decreased VD. On the other hand, controversy exists regarding the OCTA findings in eyes with PXG compared to POAG. Further comparative studies with large sample size are needed to scrutinize our results.

\section{ACKNOWLEDGEMENTS}

Funding. No funding or sponsorship was received for this study or publication of this article.

Authorship. All named authors meet the International Committee of Medical Journal Editors (ICMJE) criteria for authorship for this article, take responsibility for the integrity of the work as a whole, and have given their approval for this version to be published.

Author Contributions. Irini Chatziralli performed the literature review, analyzed and interpreted data, as well as drafted the manuscript; Ilias Milionis, Aikaterini Christodoulou and Panagiotis Theodossiadis interpreted data and critically revised the manuscript; George Kitsos conceived the topic of the review, analyzed data and critically revised the manuscript.

Disclosures. Irini Chatziralli, Ilias Milionis, Aikaterini Christodoulou, Panagiotis Theodossiadis and George Kitsos declare they do not have any conflicts of interest nor financial disclosures.

Compliance with Ethics Guidelines. This article is based on previously conducted studies and does not contain any new studies with 
human participants or animals performed by any of the authors.

Data Availability. Data sharing is not applicable to this article as no datasets were generated or analyzed during the current study.

Open Access. This article is licensed under a Creative Commons Attribution-NonCommercial 4.0 International License, which permits any non-commercial use, sharing, adaptation, distribution and reproduction in any medium or format, as long as you give appropriate credit to the original author(s) and the source, provide a link to the Creative Commons licence, and indicate if changes were made. The images or other third party material in this article are included in the article's Creative Commons licence, unless indicated otherwise in a credit line to the material. If material is not included in the article's Creative Commons licence and your intended use is not permitted by statutory regulation or exceeds the permitted use, you will need to obtain permission directly from the copyright holder. To view a copy of this licence, visit http://creativecommons.org/licenses/by$\mathrm{nc} / 4.0 /$.

\section{REFERENCES}

1. Tarkkanen A, Kivela T, John G. Lindberg and the discovery of exfoliation syndrome. Acta Ophthalmol Scand. 2002;80:151-4.

2. Schlotzer-Schrehardt U, Naumann GO. Ocular and systemic pseudoexfoliation syndrome. Am J Ophthalmol. 2006;141:921-37.

3. Streeten BW, Li ZY, Wallace RN, et al. Pseudoexfoliative fibrillopathy in visceral organs of a patient with pseudoexfoliation syndrome. Arch Ophthalmol. 1992;110:1757-62.

4. Mitchell P, Wang JJ, Smith W. Association of pseudoexfoliation syndrome with increased vascular risk. Am J Ophthalmol. 1997;124:685-7.

5. Elhawy E, Kamthan G, Dong CQ, et al. Pseudoexfoliation syndrome, a systemic disorder with ocular manifestations. Hum Genomics. 2012;6:22.
6. Ritch R, Schlötzer-Schrehardt U. Exfoliation syndrome. Surv Ophthalmol. 2001;45:265-315.

7. Ritch R. Exfoliation syndrome-the most common identifiable cause of open-angle glaucoma. J Glaucoma. 1994;3:176-7.

8. Chiras D, Kitsos G, Petersen MB, et al. Oxidative stress in dry age-related macular degeneration and exfoliation syndrome. Crit Rev Clin Lab Sci. 2015;52:12-27.

9. Henry JC, Krupin T, Schmitt M, et al. Long-term follow-up of pseudoexfoliation and the development of elevated intraocular pressure. Ophthalmology. 1987;94:545-52.

10. Weinreb RN, Aung T, Medeiros FA. The pathophysiology and treatment of glaucoma: a review. JAMA. 2014;311:1901-11.

11. Leske MC, Heijl A, Hyman L, et al. Factors for progression and glaucoma treatment: the Early Manifest Glaucoma Trial. Curr Opin Ophthalmol. 2004;15:102-6.

12. Leske MC, Heijl A, Hyman L, et al. Predictors of long-term progression in the early manifest glaucoma trial. Ophthalmology. 2007;114:1965-72.

13. Moon Y, Sung KR, Kim JM, et al. Risk factors associated with glaucomatous progression in pseudoexfoliation patients. J Glaucoma. 2017;26: 1107-13.

14. Braunsmann C, Hammer CM, Rheinlaender J, et al. Evaluation of lamina cribrosa and peripapillary sclera stiffness in pseudoexfoliation and normal eyes by atomic force microscopy. Invest Ophthalmol Vis Sci. 2012;53:2960-7.

15. Kim S, Sung KR, Lee JR, et al. Evaluation of lamina cribrosa in pseudoexfoliation syndrome using spectral-domain optical coherence tomography enhanced depth imaging. Ophthalmology. 2013;120:1798-803.

16. Yüksel N, Karabaş VL, Arslan A, et al. Ocular hemodynamics in pseudoexfoliation syndrome and pseudoexfoliation glaucoma. Ophthalmology. 2001;108:1043-9.

17. Galassi F, Giambene B, Menchini U. Ocular perfusion pressure and retrobulbar haemodynamics in pseudoexfoliative glaucoma. Graefes Arch Clin Exp Ophthalmol. 2008;246:411-6.

18. Harju M, Kurvinen L, Saari J, et al. Blood flow in the peripapillary retina in exfoliation glaucoma. Clin Exp Ophthalmol. 2008;36:738-43. 
19. Petrig BL, Riva CE, Hayreh SS. Laser Doppler flowmetry and optic nerve head blood flow. Am J Ophthalmol. 1999;127:413-25.

20. Tangtammaruk P, Petpiroon P, Supakonatanasan $\mathrm{W}$, et al. Peripapillary perfused capillary density in true versus pseudoexfoliation syndrome: an OCTA study. PLoS One. 2020;15: e0239109.

21. Borrelli E, Sarraf D, Freund KB, et al. OCT angiography and evaluation of the choroid and choroidal vascular disorders. Prog Retin Eye Res. 2018;67: 30-55.

22. Bonnin S, Mané V, Couturier A, et al. New insight into the macular deep vascular plexus imaged by optical coherence tomography angiography. Retina. 2015;35:2347-52.

23. Suwan Y, Geyman LS, Fard MA, et al. Peripapillary perfused capillary density in exfoliation syndrome and exfoliation glaucoma versus POAG and healthy controls: an OCTA study. Asia Pac J Ophthalmol. 2018;7:84-9.

24. Park JH, Yoo C, Girard MJA, et al. Peripapillary vessel density in glaucomatous eyes: comparison between pseudoexfoliation glaucoma and primary open-angle glaucoma. J Glaucoma. 2018;27: 1009-16.

25. Rebolleda G, Pérez-Sarriegui A, De Juan V, et al. A comparison of two optical coherence tomographyangiography devices in pseudoexfoliation glaucoma versus primary open-angle glaucoma and healthy subjects. Eur J Ophthalmol. 2019;29: 636-44.

26. Philip S, Najafi A, Tantraworasin A, et al. Macula vessel density and foveal avascular zone parameters in exfoliation glaucoma compared to primary openangle glaucoma. Invest Ophthalmol Vis Sci. 2019;60:1244-53.

27. Pradhan ZS, Rao HL, Dixit S, et al. Choroidal microvascular dropout in pseudoexfoliation glaucoma. Invest Ophthalmol Vis Sci. 2019;60:2146-51.

28. Çınar E, Yüce B, Aslan F. Retinal and choroidal vascular changes in eyes with pseudoexfoliation syndrome: a comparative study using optical coherence tomography angiography. Balkan Med J. 2019;37:9-14.

29. Lommatzsch C, Rothaus K, Koch JM, et al. Vessel density in glaucoma of different entities as measured with optical coherence tomography angiography. Clin Ophthalmol. 2019;13:2527-34.

30. Jo YH, Sung KR, Shin JW. Peripapillary and macular vessel density measurement by optical coherence tomography angiography in pseudoexfoliation and primary open-angle glaucoma. J Glaucoma. 2020;29:381-5.

31. Simsek M, Kocer AM, Cevik S, et al. Evaluation of the optic nerve head vessel density in the patients with asymmetric pseudoexfoliative glaucoma: an OCT angiography study. Graefes Arch Clin Exp Ophthalmol. 2020;258:1493-501.

32. Köse HC, Tekeli O. Optical coherence tomography angiography of the peripapillary region and macula in normal, primary open angle glaucoma, pseudoexfoliation glaucoma and ocular hypertension eyes. Int J Ophthalmol. 2020;13:744-54.

33. Subasi S, Yuksel N, Basaran E, et al. Comparison of vessel density in macular and peripapillary regions between primary open-angle glaucoma and pseudoexfoliation glaucoma using OCTA. Int Ophthalmol. 2021;41:173-84.

34. Safizadeh M, Shaabani A, Kamalipour A, et al. Optic nerve head vessel density in different stages of pseudoexfoliation disease. $\mathrm{Br} \mathrm{J}$ Ophthalmol. 2022;106:223-8.

35. Onur IU, Acar OPA, Cavusoglu E, et al. Vessel density in early-stage primary open angle glaucoma and pseudoexfoliation glaucoma: a comparative controlled optical coherence tomography angiography study. Arq Bras Oftalmol. 2021;84:352-60.

36. Durmuş Ece BŞ, Sarıcaoğlu MS. Examination of retinal vascular density changes via optical coherence tomography angiography in patients with glaucoma. Int Ophthalmol. 2021;41:687-98.

37. Gür Güngör S, Sarigül Sezenöz A, Öztürk C, et al. Peripapillary and macular vessel density measurement with optical coherence tomography angiography in exfoliation syndrome. J Glaucoma. 2021;30:71-7.

38. Cornelius A, Pilger D, Riechardt A, Reitemeyer E, Rübsam A, Winterhalter S, Maier AB. Macular, papillary and peripapillary perfusion densities measured with optical coherence tomography angiography in primary open angle glaucoma and pseudoexfoliation glaucoma. Graefes Arch Clin Exp Ophthalmol. (in press) https://doi.org/10.1007/ s00417-021-05321-x.

39. Kocaturk T, Isikligil I, Uz B, et al. Ophthalmic artery blood flow parameters in pseudoexfoliation glaucoma. Eur J Ophthalmol. 2016;26:124-7.

40. Neufeld AH, Liu B. Glaucomatous optic neuropathy: when glia misbehave. Neuroscientist. 2003;9: 485-95.

41. Hammer T, Schlötzer-Schrehardt U, Naumann GO. Unilateral or asymmetric pseudoexfoliation 
syndrome? An ultrastructural study. Arch Ophthalmol. 2001;119:1023-31.

42. Eltutar K, Acar F, Kayaarası Öztürker Z, et al. Structural changes in pseudoexfoliation syndrome evaluated with spectral domain optical coherence tomography. Curr Eye Res. 2016;41:513-20.
43. Campbell JP, Zhang M, Hwang TS, Bailey ST, Wilson DJ, Jia Y, Huang D. Detailed vascular anatomy of the human retina by projection-resolved optical coherence tomography angiography. Sci Rep. 2017;7:42201. 